\title{
Assessment of genetic diversity using mitochondrial DNA variation in Gir cattle of India
}

\author{
Vivek Kumar Nayak, Prajwalita Pathak and Anupama Mukherjee
}

Received: 22 April 2020 / Accepted: 23 July 2020 / Published online: 27 October 2020

(C) Indian Dairy Association (India) 2020

\begin{abstract}
The present study is carried out with the aim to study the genetic diversity of 60 Gir cattle in the newly adopted herd of NDRI on the basis of mitochondrial D-loop hyper variable region. The animals were purchased from 4 major locations-IGFRI-Jhansi, Bhilwara, Ajmer and Kisangarh. After aligning the sequences a total of 53 haplotypes were identified. The Overall haplotype Diversity was observed to be $0.996 \pm 0.003$ which shows that the population is diverse. Nucleotide diversity ranged from 0.693 \pm 0.35 to $0.707 \pm 0.35$ with overall diversity of $0.704 \pm 0.34$ across all 60 sequences and the average no. of nucleotide difference varied from $279.45 \pm 125.42$ to $285.16 \pm 128.36 . \mathrm{F}_{\mathrm{ST}}$ value is significantly different from 0 for all pair wise combinations representing significant amount of Genetic differentiation. $\mathrm{F}_{\mathrm{ST}}$ estimates between the population shows that animals from Ajmer and Bhilwara are more genetically differentiated (0.02987) while animals from Kisangarh and Bhilwara are genetically more closer $(0.00440)$. All the above results show substantial variability between populations. These findings can be used for designing proper breeding and management strategies for Gir cattle in NDRI Herd.
\end{abstract}

Keywords: Genetic Diversity, Gir cattle, Genetic Improvement, Mitochondrial DNA

\footnotetext{
Animal Genetics and Breeding division, ICAR-National Dairy Research Institute, Karnal, Haryana-132001, India

Prajwalita Pathak $(\bowtie)$

Animal Genetics and Breeding division

ICAR-National Dairy Research Institute, Karnal, Haryana-132 001, India

Email: prajwalitapathak@gmail.com
}

The most important component of any breed improvement programme is genetic diversity which is the major cause of response to selection or genetic gain and plays a major role in improving livestock. Maintaining genetic diversity should be an important task in livestock breeding as it strengthens a population by increasing the likelihood that at least some individuals will be able to survive major disturbances and it enables the population less susceptible to inherited disorders and climate change. Animal genetic resources consist of species that are of agricultural and economic importance to man and food production systems depend heavily on utilization of locally adapted animal species. Genetic diversity and population structure need to be understood for guiding breed development programs en route for meeting the current production which allows sustained genetic improvement, to facilitate adaptation, and to device proper measures of utilization and conservation of livestock breeds (Notter, 1999; Dalvit et al. 2008). Thus, assessment of population structure and genetic diversity is an important basic tool for genetic improvement through modern breeding strategies (Toro et al. 2009; Sharma et al. 2013; Chung et al. 2017). Various technologies to study genetic diversity include PCR-RFLP, minisatellites, micro-satellites, mitochondrial DNA analysis and SNP chips. The mtDNA has proved to be valuable in the study of genetic diversity as it shows maternal inheritance and changes rapidly than single copy nuclear DNA in mammals (Brown et al. 1982). The D-loop is the major control region for mitochondrial DNA (mtDNA) expression. The rate of nucleotide substitution in mtDNA is five to ten times higher than that of nuclear DNA (Brown et al. 1979). The mtDNA polymorphisms have been widely used to investigate the structure of populations, interspecies variability and identification of maternal lineages and postnatal growth (Bradley et al. 1998; Troy et al. 2001; Liu et al. 2004; Malau-Aduli et al. 2004; Yoon et al. 2005; Odahara et al. 2006; Lei et al. 2007). Considering the importance of cattle in Indian agriculture, few efforts have been made to evaluate the genetic diversity. Therefore, the present work was undertaken to quantify the genetic diversity of Gir breed of cattle in the National Dairy Research Institute, Karnal, Haryana. The objectives of this study was to use mitochondrial DNA hyper variable region polymorphisms to characterize the within-breed genetic diversity and to use the molecular information supplied to elucidate the 
genetic diversity of this breed in order to establish adequate breeding strategy.

Blood samples were collected from the standing 60 female cattle which had completed their first lactation. Around $10 \mathrm{ml}$ of venous blood was collected aseptically from the jugular vein of the animals in a $15 \mathrm{ml}$ vaccutainer tube under sterile condition using $0.5 \mathrm{ml}$ of EDTA as an anticoagulant. Blood samples were stored in $-20^{\circ} \mathrm{C}$ until DNA isolation. DNAs were extracted according to the manufacturer's standard protocol of Wizard genomic DNA purification Kit (Promega, USA). Partial mitochondrial D-loop hyper variable region was amplified using the polymerase chain reaction. The reported primer with forward 5'CCCAGGCAAGAGGTAATGTA-3' and reverse primers 5'TGTCCTGTGACCATTGACTG-3' (Bhuiyan et al. 2007) was used to amplify $588 \mathrm{bp}$ from the hyper variable region of D-loop. PCR amplification was carried out in a $25 \mu \mathrm{l}$ reaction volume containing 100ng of genomic DNA, $1 \times$ PCR master mix buffer $(50 \mathrm{mM} \mathrm{KCl}$, $10 \mathrm{mM}$ Tris-HCl, $\mathrm{pH} 8.3,1.5 \mathrm{mM} \mathrm{MgCl} 2,200 \mu \mathrm{M}$ dNTPs, 1 U Taq polymerase) (Promega, USA) and $0.5 \mathrm{pM}$ of each primer. Amplification was performed in a C1000 Thermal cycler (Applied Biosystems,USA) thermal cycler using a 10 min denaturation step followed by 30 cycles of $30 \mathrm{sec}$ at $94^{\circ} \mathrm{C}, 30 \mathrm{sec}$ at $62^{\circ} \mathrm{C}, 1 \mathrm{~min}$ at $72^{\circ} \mathrm{C}$ and a final extension at $72^{\circ} \mathrm{C}$ for $10 \mathrm{~min}$. The size of amplification product was checked by loading $5 \mu \mathrm{L}$ PCR product on to a $1.8 \%$ agarose gel containing $0.5 \mu \mathrm{L} / \mathrm{mL}$ ethidium bromide. Sequencing was done directly by Sanger DNA Sequencing method (Apical Scientific Sdn Bhd, Malaysia). The sequences of the PCR product were analyzed using Chromas software. The sequences were edited and corrected by aligning forward and reverse sequences using BLASTN. Sites representing a gap in any of the aligned sequences were excluded from the analysis. Comparison of 60 D-loop sequences of a 588-bp hyper variable region-I (HVR-I) fragment of mtDNA control region obtained from 60 Gir cattle from 4 major locations was done. Mean number of nucleotide differences $(\mathrm{k})$, nucleotide diversity $(\pi)$ within cattle

Table 1 Genetic Diversity indices of Gir cattle of different locations

\begin{tabular}{llllc}
\hline Locations & No. of Sequences & $\begin{array}{l}\text { Nucleotide Diversity } \\
(\mathrm{pi})\end{array}$ & $\begin{array}{l}\text { Avg. Nucleotide } \\
\text { Differences(k) }\end{array}$ & $\begin{array}{l}\text { Haplotype } \\
\text { Diversity(Hd) }\end{array}$ \\
\hline Jhansi & 13 & $0.704 \pm 0.36$ & $283.80 \pm 129.95$ & $1.000 \pm 0.030$ \\
Ajmer & 12 & $0.702 \pm 0.36$ & $283.24 \pm 130.49$ & $0.984 \pm 0.040$ \\
Bhilwara & 18 & $0.693 \pm 0.35$ & $279.45 \pm 125.42$ & $1.000 \pm 0.018$ \\
Kisangarh & 17 & $0.707 \pm 0.35$ & $285.16 \pm 128.36$ & $1.000 \pm 0.020$ \\
Overall & 60 & $0.704 \pm 0.34$ & $284.06 \pm 123.15$ & $0.996 \pm 0.003$ \\
\hline
\end{tabular}

Table 2 Global Fixation values between the populations

\begin{tabular}{lllll}
\hline & Jhansi & Ajmer & Bhilwara & Kisangarh \\
\hline Jhansi & & & & \\
Ajmer & 0.012 & & & \\
Bhilwara & 0.020 & 0.029 & 0.004 & \\
Kisangarh & 0.006 & 0.006 & 0
\end{tabular}

breeds, nucleotide haplotype diversity (Hd), Pair wise FST value and molecular Diversity index were calculated by Arlequin 3.1(Excoffier et al. 2006).

Alignment of 60 sequences of Gir cattle illustrated 53 different haplotypes in this investigation. Identical sequences were considered as the same haplotype.The populations from Bhilwara and Ajmer had highest no. of haplotypes with 18 and 17 respectively. The overall haplotype diversity was 0.98 throughout the population. Overall haplotype Diversity shows the population is diverse. The nucleotide diversity ranged from 0.693 to 0.707 (Table 1) with an overall nucleotide diversity of 0.704 . The average no. of nucleotide differences $(\mathrm{k})$ was 284.067 with a maximum of 285.169 in Kisangarh and minimum of 279.465 in population from Bhilwara. Tajima's D value was found to be 0.37889 , which showed that all populations evolved naturally and possesses greater genetic diversity.

In total, on an average 1092.5 variable substitutions were determined in the mtDNAs from 53 haplotypes of Gir cattle. Among them, 690 substitutions were transitions and 402.5 weretransversions $($ transitions/transversions rate $=1.72$ ) indicating a heavy bias towards transition substitution that has previously been reported for bovine mtDNA (Loftus et al. 1994; Mannen et al. 1998; Henkes et al. 2005; Bhuiyan et al. 2007 and Sharma et al. 2015).

Table 2 represents Global Fixation values between the populations. FST value are significantly different from 0 for all pair wise combinations representing significant amount of Genetic differentiation between population. The mean sequence divergence values ranged between 0.029 to 0.004 among different populations. FST estimates between the population shows that animals from Kisangarh and Bhilwara are more genetically differentiated while animals from Ajmer and Bhilwara are genetically closer values for pair wise FST was significant for populations of Ajmer and Bhilwara. Similarly, AMOVA revealed 
that percent of variation among the populations was $0.61 \%$ while within the population it was $99.39 \%$.

\section{Conclusions}

This study involves detailed analysis of the genetic diversity and indicates existence of genetic diversity and population structure in Gir cattle. It could generate the baseline information which will assist in formulating effective breeding strategies in future for overall genetic improvement of Gir cattle in the NDRI herd. However a well defined breeding plan is a must to maintain the existing genetic diversity which will help the future bull mother farm to assist in dissemination of high merit germplasm to the farmer's herd.

\section{Acknowledgements}

The authors are thankful to the Director of ICAR-NDRI and Head of the Division, AGB, NDRI, Karnal for providing the necessary facilities. We wish to acknowledge the hard work and sincerity of the staffs of Livestock Research centre.

\section{References}

Bhuiyan MSA, Bhuiyan AKFH, Yoon DH, Jeon JT, Park CS, Lee JH (2007) Mitochondrial DNA diversity and origin of Red Chittagong Cattle. Asian-Aust J Anim Sci 20: 1478-1484

Bradley DG, MacHugh DE, Cunningham P, Loftus RT (1998) Mitochondrial diversity and the origins of African and European cattle. Proc Natl Acad Sci 93: 5131-5135

Brown WM, George M Jr, Wilson AC (1979) Rapid evolution of animal mitochondria DNA. Proc Natl Acad Sci 76: 1967-1971.

Brown W M, Prager E M, Wang A, Wilson A C (1982) Mitochondrial DNA sequences of primates: Tempo and mode of evolution. J Mol Evol 18: $225-239$

Chung N C, Szyda J, Frąszczak M (2017). Population structure analysis of bull genomes of European and Western ancestry. Scientific Reports 7: 40688

Dalvit C, De Marchi M, Targhetta C, Gervaso M, Cassandro M (2008) Genetic traceability of meat using microsatellite markers. Food Res Int 41: 301-307

Excoffier L, Laval G, Schneider S (2006) Arlequin ver 3.01: An integrated software package for population genetics data analysis. University of Berne. Switzerland
Lee YJ, Bhuiyan MSA, Chung HJ, Jung WY, Choi KD, Jang BG, Paek WK, Jeon JT, Park CS, Lee JH (2007) Mitochondrial DNA diversity of Korean Ogol chicken. Asian-Aust J Anim Sci 20: 477-481

Lai SJ, Liu YP, Liu YX, Li XW, Yao YG (2006) Genetic diversity and origin of Chinese cattle revealed by mtDNA D-loop sequence variation. Mol Phyl Evol 38: 146-154

Liu MH, Kantanen J (2009) Genetic structure of Eurasian cattle (Bos taurus) based on microsatellites: clarification for their breed classification. Anim Genet 41: 150-158

Malau-Aduli AEO, Nishimura-Abe A, Niibayashi T, Yasuda Y, Kojima T, Abe S, Oshima K, Hasegawa K, Komatsu M (2004) Mitochondrial DNA polymorphism, maternal lineage and correlations with postnatal growth of Japanese Black beef cattle to yearling age. Asian-Australas J Anim Sci 17: 1484-1490

Notter DR (1999). The importance of genetic diversity in livestock population of the future. J Anim Sci 77: 61-69

Odahara S, Chung HJ, Choi SH, Yu SL, Sasazaki S, Mannen H, Park CS, Lee JH (2006) Mitochondrial DNA diversity of Korean native goats. Asian-Australas J Anim Sci 19: 482-485

Sharma R, Maitra A, Singh PK, Tantia MS (2013) Genetic diversity and relationship of cattle populations of East India: distinguishing lesser known cattle populations and established breeds based on STR markers. Springer Plus 2: 359

Sharma R, Kishore A, Mukesh M, Ahlawat S, Maitra A, Pandey AK, Tantia MS, (2015) Genetic diversity and relationship of Indian cattle inferred from microsatellite and mitochondrial DNA markers. Bio Med Central Genet 16: 73-84

Toro M, Ferna'ndez J and Caballero A (2009) Molecular characterization of breeds and its use in conservation. Livest Sci 120: 174-195

Troy CS, MacHugh DE, Bailey JF, Magee DA, Loftus RT, Cunningham P, Chamberlain AT, Sykes BC and Bradley DG (2001) Genetic evidence for near-eastern origins of European cattle. Nature 410: 1088-1091

Woolliams J A (2005) Sustainable management of animal genetic resources. Nordic Gene Bank Farm Animals. ISBN 92-893-1089-8

Yoon DH, Lee HK, Oh SJ, Hong KC, Jeon GJ, Kong HS and Lee JH (2005) Genetic relationships of cattle breeds assessed by PCR-RFLP of the bovine mitochondrial DNA D-loop region. Asian-Australas J Anim Sci 18: 1368-1374 